\title{
大気中における粒子状 $\mathrm{NO}_{3}^{-}$と気体状 $\mathrm{HNO}_{3}$ の挙動( II )
}

\section{Particulate Nitrate and Gaseous Nitric Acid in the Atmosphere (II)}

玉 置 元 則*

\section{3. 大気中の濃度}

\section{1 粒子状 $\mathrm{NO}_{3}{ }^{-}$の濃度}

表 7 亿わが国の国設大気污染測定網で測定された粒 子状 $\mathrm{NO}_{3}{ }^{-}$濃度 ${ }^{52)}$ ならびに全粒子状物質中に占める 割合の年平均值を測定年度でとに示す. 年平均值で見 た場合, $3 \sim 5 \mu \mathrm{g} / \mathrm{m}^{3}$ の粒子状 $\mathrm{NO}_{3}{ }^{-}$が大気中に存在 し，それは全粒子状物質の $5 \%$ 近くを占めている。乙 のデータは Hi-Volによりガラス繊維ろ紙を用いて測 定されたあのであり, その後1979 年 4 月より石英織維 ろ紙を用いて同様に粒子状物質が測定されている。表 8 に, わが国の個々のグループにより測定された粒子 状 $\mathrm{NO}_{3}{ }^{-}$の濃度の一例を示す53 66).

米国においても, 従来主にガラス瀻維ろ紙を用いて 粒子状物質は測定されており, おおむね $2 \sim 3 \mu \mathrm{g} / \mathrm{m}^{3}$ の $\mathrm{NO}_{3}{ }^{-}$濃度が示されている671。世界各地で測定さ れた粒子状 $\mathrm{NO}_{3}{ }^{-}$濃度の一例を表 9 亿示す.

$\mathrm{ACHEX}$ の1972 73 年のデータでは68)， $\mathrm{NO}_{3}{ }^{-}$は TSP の15\%以上を占めたり， 2 時間值で149 $\mu \mathrm{g} / \mathrm{m}^{3}$ 之 いう高い値を示すととがあるとと，Grosjean 等も短時 間捕集で5)，60 $\mathrm{mg} / \mathrm{m}^{3}$ 以上の高い值を報告しているが， このような值はかなりきびしいスモッグ時に限られる ようである.

Spicer は 3 年間にわたる $\mathrm{NO}_{\mathrm{x}}$ の光化学スモッグに 対する役割を研究するなかで21)，粒子状 $\mathrm{NO}_{3}$ ににつ いてもそのデータの一部を示している.それによるよ 分級しない全粒子中で $\mathrm{NO}_{3}{ }^{-}$は0.40 1.7 wt.\%を占め
るが, $2.0 \mu \mathrm{m}$ 以上の粗大粒子 (Large particle) では 2.6 7.7 wt.\%とその占める割合が大きくなるととを 示している（表10）.こてでは, 粒子状 $\mathrm{NO}_{3}{ }^{-}$の平均濃 度等を示していないが，別にまとめた結果では136)， 粒子状 $\mathrm{NO}_{3}{ }^{-}$濃度はかなり低い値として示されている.

Heidorn はカナダの Ontario で23の測定地点で $\mathrm{SO}_{4}{ }^{2-}$ と $\mathrm{NO}_{3}{ }^{-}$を測定し, 1971 年の値と 1976 年の値を 比較している ${ }^{69)}$. 1971 年には平均値が $2.57 \mu \mathrm{g} / \mathrm{m}^{3}$ で あったが, 1976 年には2.81 $\mu \mathrm{g} / \mathrm{m}^{3}$ に增加している。 こ れに対し $\mathrm{SO}_{4}{ }^{2-}$ はこの 5 年間で濃度が減少している.

表 7 わが国各地の粒子状 $\mathrm{NO}_{3}$ 一濃度ならびにその全 粒子状物質中に占める割合の年平均値 ${ }^{571}$

（国設大気污染測定網）

\begin{tabular}{|c|c|c|c|c|c|c|c|}
\hline \multirow{2}{*}{$\begin{array}{l}\text { 測定 } \\
\text { 年度 }\end{array}$} & \multirow{2}{*}{ 測定 } & \multicolumn{2}{|c|}{ 平 均 值 } & \multicolumn{2}{|c|}{ 最 高 值 } & \multicolumn{2}{|c|}{ 最 低 值 } \\
\hline & & $\mu g / \mathrm{m}^{3}$ & $\%$ & $\mu g / \mathrm{m}^{3}$ & $\%$ & $\mu g / \mathrm{m}^{3}$ & $\%$ \\
\hline 45 & 11 & 4.7 & 2.4 & 6.8 & 5.7 & 2.9 & 1.1 \\
\hline 46 & 14 & 3.1 & 1.7 & 5.3 & 4.2 & 0.8 & 0.7 \\
\hline 47 & 15 & 5.0 & 3.1 & 11.8 & 4.0 & 1.8 & 1.1 \\
\hline 48 & 15 & 4.4 & 2.8 & 8.2 & 6.0 & 2.2 & 1.4 \\
\hline 49 & 16 & 3.5 & 2.8 & 5.6 & 4.2 & 1.5 & 1.3 \\
\hline 50 & 18 & 4.4 & 4.2 & 8.6 & 6.4 & 1.6 & 1.5 \\
\hline 51 & 21 & 4.1 & 3.6 & 7.2 & 4.9 & 1.5 & 1.6 \\
\hline 52 & 23 & 4.0 & 4.6 & 7.3 & 7.4 & 1.4 & 1.8 \\
\hline 53 & 23 & 3.2 & 3.4 & 6.2 & 6.2 & 1.2 & 1.1 \\
\hline
\end{tabular}
值のうち, 测定月数が $12 か$ 月に満たない測定局の値は除いた。

*兵庫県公害研究所, 主任研究員, 工博

The Environmentel Science Inst it ute of Hyogo Prefect ure, Motonori Tamaki 
表 8 わが国の各地で測定された粒子状 $\mathrm{NO}_{3}$-濃度の一例

\begin{tabular}{|c|c|c|c|c|c|c|c|c|}
\hline \multicolumn{3}{|c|}{$\mathrm{NO}_{3}$-濃度 $\left(\mu \mathrm{g} / \mathrm{m}^{3}\right)$} & \multirow{2}{*}{ 測定場所 } & \multirow{2}{*}{ 測 定 期 間 } & \multirow{2}{*}{$\begin{array}{c}\text { 時 間 } \\
(\mathrm{h})\end{array}$} & \multirow{2}{*}{ ろ } & \multirow{2}{*}{ 備 } & \multirow{2}{*}{ 文 献 } \\
\hline 平均 & 最 高 & 最 低 & & & & & & \\
\hline $\begin{array}{l}3.8 \\
3.4 \\
4.1 \\
3.2 \\
2.8\end{array}$ & $\begin{array}{c}<6.6> \\
6.8 \\
<4.2> \\
\\
\\
\\
(5.5) \\
<7.0> \\
44.7 \\
(12) \\
(20) \\
<5.4> \\
(8)\end{array}$ & $\begin{array}{c} \\
(1.0) \\
\langle 4.6> \\
(2.0) \\
(0.5) \\
(1.0) \\
<2.8> \\
(3)\end{array}$ & 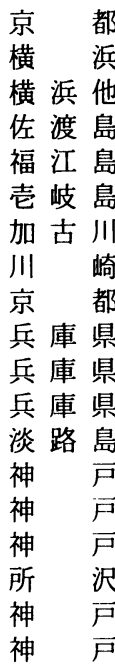 & $\begin{array}{l}74.8 \sim 75.1 \\
74.3 \sim 75.3 \\
75.7 \sim 76.1 \\
75.10 \\
75.10 \\
75.10 \\
75.7 \sim 8 \\
72 . \sim 74 . \\
(75 .) \quad 6 \sim 9 \\
75.7 \sim 76.2 \\
\text { 夏 } \\
\text { 春, 夏, 冬 } \\
78.7 \sim 8 \\
78.2 \\
78.8 \\
79.2 \sim 3 \\
78.7 \\
76.7 \sim 77.2 \\
76.11\end{array}$ & $\begin{array}{c}24 \\
3(9) \\
1 \\
1 \\
12 \\
1 \\
2 \\
1 \\
1 \\
\text { 尽 · 夜 } \\
\text { 昼 - 夜 }\end{array}$ & $\begin{array}{l}\text { 石英 } \\
\left\{\begin{array}{l}\text { 石英 } \\
(\text { Pall flex })\end{array}\right. \\
\text { 石英 } \\
\text { (Pall flex) }\end{array}$ & $\begin{array}{l}\text { 離島 } \\
\text { 製鉄所周辺 } \\
\text { セxント工場 } \\
\text { 光化学 } \\
\text { 非污染地域 }\end{array}$ & $\begin{array}{l}53 \\
54 \\
55 \\
56 \\
56 \\
56 \\
57 \\
58 \\
59 \\
60 \\
61 \\
62 \\
63 \\
64 \\
64 \\
64 \\
65 \\
66 \\
66\end{array}$ \\
\hline
\end{tabular}

測定はほとんど Hi－Vol による。

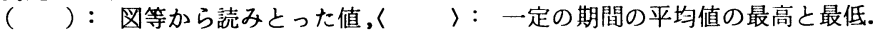

表 9 世界各地で測定された粒子状 $\mathrm{NO}_{3}$ 一濃度の一例

\begin{tabular}{|c|c|c|c|c|c|c|c|c|c|}
\hline \multicolumn{3}{|c|}{$\mathrm{NO}_{3}$ - 濃度 $\left(\mu \mathrm{g} / \mathrm{m}^{3}\right)$} & \multirow{2}{*}{$\mathrm{n}$} & \multirow{2}{*}{ 測 定 場 所 } & \multirow{2}{*}{ 測 定 期 間 } & \multirow{2}{*}{${ }^{\text {時 }}(\mathrm{h})^{\text {間 }}$} & \multirow{2}{*}{ 捕 集 法（ろ紙） } & \multirow{2}{*}{ 備 } & \multirow{2}{*}{ 文献 } \\
\hline 平均 & 最 高 & 最 低 & & & & & & & \\
\hline 2.61 & 5.20 & 1.21 & 9 & \multirow{3}{*}{$\begin{array}{l}\text { West Covina } \\
\text { (CA) }\end{array}$} & \multirow{3}{*}{$\begin{array}{l}73.7 \\
\text { (スモッグ時) }\end{array}$} & \multirow[t]{3}{*}{2} & \multirow[t]{3}{*}{ ガラス㵶維 } & \multirow{3}{*}{$\begin{array}{l}\mathrm{MS} \text { 法 } \\
\mathrm{NH}_{4} \mathrm{NO}_{3} \\
\mathrm{NaNO}_{3}\end{array}$} & \multirow[t]{3}{*}{74} \\
\hline 2.15 & 4.6 & 0.98 & 9 & & & & & & \\
\hline 0.46 & 0.68 & 0.11 & 9 & & & & & & \\
\hline 54.3 & 86 & 18 & 11 & $\begin{array}{l}\text { Riverside } \\
(\mathrm{CA})\end{array}$ & $77.7 \sim 10$ & 24 & $\begin{array}{l}\text { Gelman AE } \\
\mathrm{Hi}-\mathrm{Vol}\end{array}$ & $\begin{array}{l}\mathrm{HNO}_{3}, \mathrm{NH}_{3} \\
\text { 高濃度時 }\end{array}$ & 30 \\
\hline 6.49 & 18.9 & 0.4 & 9 & Pittburg ( $\mathrm{CA})$ & 79.2 & 8 & テフロン & \multirow{5}{*}{ 万紙間比較 } & 24 \\
\hline 1.46 & 1.9 & 0.7 & 5 & \multirow{4}{*}{$\begin{array}{l}\text { Upland } \\
(\mathrm{CA})\end{array}$} & $76.10 \sim 11$ & 8 & 石英 (ADL) & & \multirow[t]{4}{*}{8} \\
\hline 1.60 & 3.1 & 0.4 & 23 & & & 8 & 石英（QAST） & & \\
\hline 16.53 & 28.7 & 9.1 & 6 & & & 8 & ガラス（Gelman A A ) & & \\
\hline 8.69 & 18.4 & 3.9 & 7 & & & 8 & ガラス（Gelman A） & & \\
\hline 1.61 & 3.94 & 0.28 & 13 & Upton (NY) & $78.6 \sim 7$ & $2 \sim 18$ & 石英 & & 23 \\
\hline 1.46 & 2.7 & 0.3 & 10 & 筑波山 & 75.10 & 2 & テフロン（Millipore & & 4 \\
\hline \multirow[t]{2}{*}{ (3.3) } & $(10.0)$ & $(0.9)$ & 24 & 東京 & 76.1 & & FHLP) & 日平均 & \\
\hline & $\langle 31.5\rangle$ & $\langle 4.1\rangle$ & & $\begin{array}{l}\text { South Coast } \\
\text { Air Basin( }(\mathrm{CA})\end{array}$ & 72. $\sim 73$. & 24 & $\begin{array}{l}\text { セルロース } \\
\text { (Whatman 41) }\end{array}$ & & 73 \\
\hline 3.3 & 9.2 & 0.9 & 5 & Gothenburg & 77.10 & (24) & テフロン（Millipore） & 都市部 & 99 \\
\hline 2.1 & 5.4 & 0.7 & 5 & $\begin{array}{l}\text { Rörvik } \\
\text { スエーデン }\end{array}$ & 77.10 & & & 後背地 & \\
\hline 2.57 & 4.2 & 0.4 & & カナダ & 71. & 24 & （ガラス瀻維） & & 69 \\
\hline 2.81 & 7.8 & 1.0 & & Ontario & 76. & 24 & $\mathrm{Hi}-\mathrm{Vol}$ & & \\
\hline $\begin{array}{l}1.9 \\
0.83\end{array}$ & & & & SArizona & 73.12 & 24 & $\begin{array}{l}\mathrm{Hi}-\mathrm{Vol} \\
\text { ガラス (Gelman A) }\end{array}$ & $\begin{array}{l}\text { 都市部 } \\
\text { 後背地 }\end{array}$ & 70 \\
\hline 0.93 & & & 202 & ドイッ（GFR） & $71.11 \sim 73.12$ & $2 ２ 5$ 日 & （ガラス縅維） & 山中 & 97 \\
\hline
\end{tabular}

$\mathrm{NO}_{3}$ - 濃度のうち（）：図等から読みとった值,〈 〉：一定の期間の平均值の最高と最低. 
表10 エアロゾル組成の一例（重量\%）211

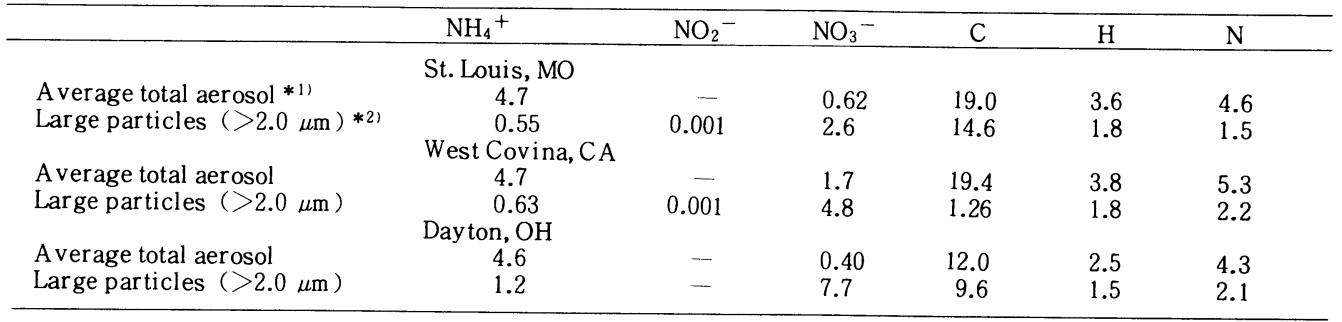

*1）分級しないで捕集した全粒子の平均

Moyer 等は米国の乾燥地帯 Arizona の都市打よび 後背地で粒子状物質を捕集し，23の化学成分について 分析し，その相互間の関係を解析している70)。都市 部で $1.9 \mu \mathrm{g} / \mathrm{m}^{3}$, 後背地で $0.83 \mu \mathrm{g} / \mathrm{m}^{3}$ の平均值を示す が，他の物質とあまり相関関係がないとしている。

Dams 等はベルギーで粒子状物質中の全化学分析と 銘うって, 50 以上の成分を分析しているが, $\mathrm{NO}_{3}{ }^{-}$は $\mathrm{NH}_{4}{ }^{+}$の約 6 倍, $\mathrm{SO}_{4}{ }^{2-}$ の約 $1 / 4$ の値として示してい る71)。さらに彼等は高濃度エピソード時に扔いて同様 の分析をし, $\mathrm{NO}_{3}$ に については1.3 33.0 $\mathrm{\mu g} / \mathrm{m}^{3}$ の值を 示している72).

\section{2 粒子状 $\mathrm{NO}_{3}$-の経時変化ならびに他の污染質と の関係}

前述のように, 従来得られている粒子状 $\mathrm{NO}_{3}{ }^{-}$の データはガラス緘維ろ紙を用いたものが多く, artifa$\mathrm{ct} \mathrm{NO}_{3}{ }^{-}$がそのなかに含まれていると考えられる.し たがって, 次に示す粒子状 $\mathrm{NO}_{3}{ }^{-}$の経時変化等につい て報告されたうちにも，その影響を受けているものが 多いと考えられる.

Grosjean 等は Pasadena（Los Angeles）でオゾン 高濃度時に得た粒子状物質中の $\mathrm{NO}_{3}{ }^{-}$濃度の経時変化 を示した ${ }^{5)}$. そ扎によると $\mathrm{NO}_{3}{ }^{-}$はオゾンおよび $\mathrm{PA}$ $\mathrm{N}$ と同じ経時変化を示し, 昼すぎに最高濃度を示す. さらに $\mathrm{NH}_{4}{ }^{+}, \mathrm{SO}_{4}{ }^{2-}, \mathrm{NO}_{3}{ }^{-}$, 粒子状有機物の総和 あオン゙ンと同じ経時変化を示した。

我々は神戸において1976〜1977 年に石英瀻維万紙を 用いて粒子状物質を捕集し，そのなかに含まれる $\mathrm{NO}_{3}{ }^{-}$ 等を分析した ${ }^{66)}$. その結果, $\mathrm{NO}_{3}{ }^{-}$濃度の季節別変 動は顕著ではないが, 昼間に比較して夜間に低い值が 出現するととを示した.

一方, Hidy 等は Californiaに おる る大規模の野外 調査, ACHEX (California Aerosol Characterization Experiment) の結果 ${ }^{68)}, \mathrm{NO}_{3}{ }^{-}$の最大值は早朝 に現われることを示した。つまり，日中の相対湿度
（RH）の減少が始まる前の時期で, 自動車の朝の走

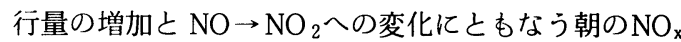
ピークとともに現われることを示した.ACHEX調査 のうち, 特に $\mathrm{NO}_{3}{ }^{-}$と $\mathrm{SO}_{4}{ }^{2-}$ の挙動をとり出して後 に報告した結果では ${ }^{73)} ， 0.5 \mu \mathrm{m}$ 以下の粒子に含まれ る $\mathrm{NO}_{3}{ }^{-}$は昼ごろにピークがあるが，分級しないトー タルの粒子中では朝にピークがあることを示している. また Cronn 等は $\mathrm{NaNO}_{3}$ の時間的変動は少ないが, $\mathrm{NH}_{4} \mathrm{NO}_{3}$ は朝にピークがあるととを示している74).

しかしながら，てれらの $\mathrm{NO}_{3}$ ヒピークが現われる早 朝は RHならびに $\mathrm{NO}_{\mathrm{x}}$ 濃度等が高いため, 乙の現象 が熱化学的な $\mathrm{NO}_{3}{ }^{-}$の生成という大気中の挙動を反映 しているのか， ろ紙上でのみ起てるてとなのかについ ては今のとてろまだ判断できないようである. Spicer は朝にピークのあるのは主にろ紙上の反応で，捕集時 間が短かいとと, 高い $\mathrm{RH}$, 高い $\mathrm{NO}$ x濃度がそれをも たらしているのではないかと推測している211.

\section{3 粒子状 $\mathrm{NO}_{3}$ - 濃度と $\mathrm{NO}_{\mathrm{x}}$ 濃度との関係}

大気中に放出された $\mathrm{NO}_{\mathrm{x}}$ のかなりの量は大気中で 粒子状 $\mathrm{NO}_{3}{ }^{-}$に変化していく.したがって，大気中で 検出される粒子状 $\mathrm{NO}_{3}{ }^{-}$の大部分は，いかなる化学 的・物理的過程を経て生成されたかは別にして, $\mathrm{NO}_{\mathrm{x}}$ から変化して生成されたものである.しかしながら， 大気中の $\mathrm{NO}_{x}$ 濃度と粒子状 $\mathrm{NO}_{3}{ }^{-}$濃度については明 確な関係が呈示されていない。

Sandberg 等は San Francisco 地域で $\mathrm{SO}_{4}{ }^{2-}$ ¿ $\mathrm{SO}_{2}$, 抢よび $\mathrm{NO}_{3}{ }^{-}$と $\mathrm{NO}_{\mathrm{x}}$ との濃度の関係を求めたが ${ }^{67)}$, $\mathrm{NO}_{3}{ }^{-}$と $\mathrm{NO}_{\mathrm{x}}$ との間にはほとんど相関関係が認められ なかったと報告している。

Grosjean 等は $\mathrm{NO}_{3}{ }^{-}$と $\mathrm{NO}_{\mathbf{x}}$ 濃度間の関係を示すの 亿 $f_{\mathrm{N}}=\mathrm{NO}_{3}^{-} /\left(\mathrm{NO}_{\mathrm{x}}+\mathrm{NO}_{3}^{-}\right)$を用いている5 。乙 のガス一粒子分布ファクターは同じように有機物 $\left(f_{\mathrm{c}}\right)$, $\mathrm{SO}_{4}{ }^{2-}\left(f_{\mathrm{S}}\right)$ についてあ用いられ, Pasadena で高い $\mathrm{O}_{3}$ 濃度時期に測定した結果に適用したとてろ，粒子状 
の二次污染物の濃度は有機物 $>\mathrm{NO}_{3}{ }^{-}>\mathrm{SO}_{4}{ }^{2-}$ の順に なるのに対し, 分布ファクターは $f_{\mathrm{S}}>f_{\mathrm{N}}>f_{\mathrm{C}}$ と逆の 順になることを示した。また，視程障害を示す尺度で ある $b$ scat と $\mathrm{NO}_{3}{ }^{-}$濃度との間には良い相関関係が成 りたつと報告している.

Hidy 等は, $\left(0.5 \mu \mathrm{m}\right.$ 以下の粒子中の $\left.\mathrm{NO}_{3}{ }^{-}\right) / \mathrm{NO}_{2}$ と $\mathrm{O}_{3}$ との間吘よび（全粒子中の $\mathrm{NO}_{3}{ }^{-}$) $/ \mathrm{NO}_{2}$ と $\mathrm{O}_{3}$ との間には明りょうな関係が認められなかったと報告 している68).

てのように，たしかに大気中に打ける粒子状 $\mathrm{NO}_{3}{ }^{-}$ 濃度と $\mathrm{NO}_{\mathrm{x}}$ 濃度との関係を見ていく場合, 種々の化学 的素反応以外汽気象的・地理的因子を考慮する必要か あり，現段階に扑てては一律な評価は困難と思われる. 特に $\mathrm{NO}_{\mathrm{x}} \rightarrow \mathrm{NO}_{3}{ }^{-}$が一段で生成される以外に $\mathrm{HNO}_{3}$ を経由するあのが多いため, 時間の因子が大きいと考 えられる。しかしながら，今後デー夕を積み重ねるて とにより， $\mathrm{NO}_{x}$ 濃度がふえれば, $\mathrm{NO}_{3}{ }^{-}$濃度もふえ るという，おおざっぱな関係は示されそうである1，75)。

また，我々が神戸市で測定したデータからは，気体 状 $\mathrm{NO}_{\mathrm{x}}$ 濃度ならびに TSP 濃度が増加すると, 粒子状 $\mathrm{NO}_{3}{ }^{-}$濃度が増加する傾向が認められた ${ }^{66)}$.

\section{4 粒径分布と化学組成}

大気中に浮遊している粒子中において $\mathrm{NO}_{3}{ }^{-}$は単一 組成を有していることは極めてまれである.すなわち， $\mathrm{NH}_{4} \mathrm{NO}_{3}$ や $\mathrm{NaNO}_{3}$ の結晶として存在したり，てれらと $\mathrm{H}_{2} \mathrm{O}$ のみで droplet を形成している例はほとんどない. 大気中でガス状物質から極めて細かい粒子が生成され， 成長するか，ある程度の既存粒子があると，それに大 気中の $\mathrm{NH}_{3}, \mathrm{SO}_{\mathrm{x}}, \mathrm{NO}_{\mathrm{x}}$ 等のガス状物質が吸収された り, 粒子間の凝集によりさらに成長していく.

したがって，大気中の粒子中に抢いては種々のイオ ン（塩，酸）が共存しており，それらはガス成分の平 衡状態，蒸気圧，塩等の解離常数等に支配され，新た な塩あるいは酸として共存する可能性がある．そのた め，粒子中の $\mathrm{NO}_{3}^{-}$の性状を知るためには，それが含 まれている粒子（群）の化学組成と粒径を知る必要が あり，乙れは同時にその粒子全般あるいは $\mathrm{NO}_{3}$ - の大 気中での起源, 变化過程の一端をあ明らかにするあの である.

1968 年に Lee と Patterson はカスケード・インパク ターを用いて。主に24時間粒子を分級捕集し，そのな かに含まれる $\mathrm{NO}_{3}{ }^{-}$等の粒径分布を示した ${ }^{76)}$

Lund grenは彼の開発したインパクターを用い, 1968 年に Riverside (California) で大気中の粒子状
物質を捕集し，高スモッグ時に 0.5 2 $2 \mu \mathrm{m}$ の領域に $\mathrm{NH}_{4} \mathrm{NO}_{3}$ が存在することを示した ${ }^{77)}$.

Gordon 等もIR 等を用い, $\mathrm{NO}_{3}{ }^{-}$と $\mathrm{NH}_{4}{ }^{+}$のモル比 から Los Angeles の大気中で $\mathrm{NH}_{4} \mathrm{NO}_{3}$ が存在するて とを示している ${ }^{78)}$. Cunningham 等は Lund gren 1 ンパクターを用いて粒子を分級捕集し，それぞれのス テージで捕集した粒子を用いて $\mathrm{KBr}$ ペレットを作成し， $\mathrm{FT}-\mathrm{IR}$ で $1384 \mathrm{~cm}^{-1}$ の $\mathrm{NO}_{3}{ }^{-}$特性吸収帯を用いて $\mathrm{NO}_{3}{ }^{-}$を定量し, その経時変化を示した ${ }^{79}$.また, Lee 等は米国のカスケード・インパクターによる測定網で の 3 年間の測定結果を1976 年に発表したが，乙てでは 化学成分との対応は示されていない80).

角脇は名古屋に打いて，アンダーセン・カスケード・ インパクターにより大気中の粒子状物質を捕集し, $\mathrm{NO}_{3}$ 一等の粒径分布を測定した ${ }^{811}$ 。 その結果, TSP

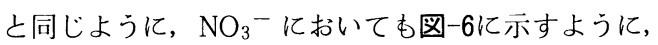

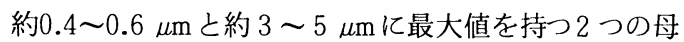
集団（bi-modal）を形成するてとを示した。また冬に は細かい粒子の属する集団に $\mathrm{NO}_{3}{ }^{-}$が多く, 夏には大 きい粒子の属する集団に $\mathrm{NO}_{3}{ }^{-}$が多いことを示し， ペーパークロマトグラフ法により ${ }^{821}$ ，それぞれが $\mathrm{NH}_{4}$ $\mathrm{NO}_{3}, \mathrm{NaNO}_{3}$ が主成分であると推定した。

Moskowitz 等は Los Angeles 地域で粒子状 $\mathrm{NO}_{3}{ }^{-}$ 等を測定し, 都市部の Pasadena では0.05〜 $1 \mu \mathrm{m}$ と $2 \sim 8 \mu \mathrm{m}$ 亿最大值を有する bi-modal を示し, 農村 部の Chino では bi-modal は弱く, サブミクロン領域 に多いとと，さらに海岸部の Hermosa Beach では 2 $8 \mu \mathrm{m}$ にほとんどの $\mathrm{NO}_{3}$-が含まれるてとを報告した ${ }^{83}$. Cronn 等は 1973 年の光化学スモッグ高濃度時に California 南部でガラス繊維ろ紙上に捕集した $3.5 \mu \mathrm{m}$

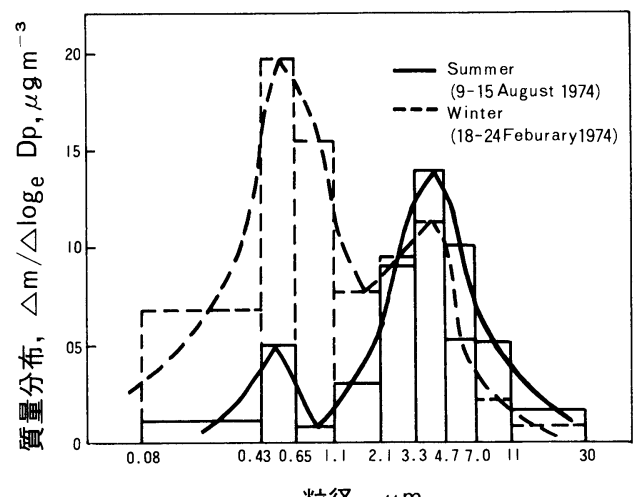

粒径, $\mu \mathrm{m}$

図-6 名古屋に扮ける粒子状 $\mathrm{NO}_{3}$ - の粒径分布 ${ }^{81)}$ 
表11 South Coast Air Basin (California)で1973 年 に測定された粒子状物質のm.m.d.值 ${ }^{73)}$

\begin{tabular}{|c|c|c|}
\hline $\begin{array}{llll}\text { 測 } & \text { 定 } & \text { 場 } \\
\text { 測 } & \text { 定 } & \text { 期 } & \text { 間 }\end{array}$ & $\begin{array}{l}\mathrm{NO}_{3}^{-} \\
(\mu \mathrm{m})\end{array}$ & $\begin{array}{l}\mathrm{SO}_{4}{ }^{2-} \\
(\mu \mathrm{m})\end{array}$ \\
\hline \multicolumn{3}{|l|}{ Dominguez Hills } \\
\hline Oct. $4-5$ & 1.64 & 0.43 \\
\hline Oct. $10-11$ & 0.72 & 0.42 \\
\hline \multicolumn{3}{|l|}{ West Covina } \\
\hline $\begin{array}{l}\text { July } 23-24 \\
\text { July } 26 *)\end{array}$ & 1.13 & 0.34 \\
\hline \multicolumn{3}{|l|}{ Pomona } \\
\hline $\begin{array}{l}\text { Aug. } 16-17 \\
\text { Rubidoux }\end{array}$ & 0.68 & 0.39 \\
\hline Sept. $5-6$ & 0.33 & 0.33 \\
\hline Sept. $18-19$ & 0.34 & 0.43 \\
\hline
\end{tabular}

5 段の Lundgren インパクターを用いて24時間捕集した値

*) 13時間の平均值（ 5 時〜18時）

以下の粒子状物質を高分解能の質量分析計を用いてそ の化学組成を分析した ${ }^{74}$. 特任熱江対する安定性の差 を利用して $\mathrm{NH}_{4} \mathrm{NO}_{3}$ と $\mathrm{NaNO}_{3}$ を分別定量した。その 結果, $\mathrm{NH}_{4} \mathrm{NO}_{3}$ は0.98 4.6 $\mu \mathrm{g} / \mathrm{m}^{3}$ (平均 $2.15 \mu \mathrm{g} / \mathrm{m}^{3}$ ), $\mathrm{NaNO}_{3}$ は0.11 0.68 $\mu \mathrm{g} / \mathrm{m}^{3}$ (平均0.46 $\mu \mathrm{g} / \mathrm{m}^{3}$ ) という 濃度を示した。しかし, 湿式の化学分析の結果之は必 ずしも良い一致は得られなかったようである。

また，Grosjean 等は1Rによる分析より， $\mathrm{NO}_{3}$-の うち $95 \%$ は $\mathrm{NH}_{4} \mathrm{NO}_{3}$ であると報告している5)。さらに ACHEX の結果からは, $\mathrm{SO}_{4}{ }^{2-}$ に比へてて $\mathrm{NO}_{3}{ }^{-}$の粒 径は大きく，それはほとんど $\mathrm{NH}_{4} \mathrm{NO}_{3}$ 之考えられてい るようである. 1973 年に Lund gren インパクターで測 定した結果では, 重量基準中央径, m.m.d.(mass median dimeter) は, $\mathrm{SO}_{4}{ }^{2}$ について $<0.22 \sim 0.43$ $\mu \mathrm{m}, \mathrm{NO}_{3}-$ については $0.33 \sim 1.64 \mu \mathrm{m}$ の值が示され ている（表11） ${ }^{73)}$.

また, Spicer は2.0 $\mu \mathrm{m}$ 以上の粒子中で $\mathrm{NO}_{3}{ }^{-}$が占 める割合が高いことを示している211。一方, Walker 等は夜間のビル内で粒子状物質を分級捕集し, $\mathrm{NO}_{3}{ }^{-}$ は主に1.1 2.0 $\mu \mathrm{m}$ の粒径に存在することが多いと報 告している ${ }^{84)}$.

\section{5 個々の粒子についての分析}

粒子状物質の測定は，たとえある程度の粒径別に分 級捕集したにしても，大気中に浮遊している個々の粒 子（induvidual particle）の集積物としてなされる ため，その総体としての性状しか明らかにされ得ない。 近年 X線マイクロアナライザ一等を用いて個々の粒子 の性状を明らかにするててろみがなされるようになった。

Mamane と Pueschel は純粋な $\mathrm{NO}_{3}$-粒子ならびに
大気中のサブミクロン〜ミクロンの粒径の個々の粒子 に対する定量的な分析法を開発した ${ }^{85}$. この方法は $\mathrm{NO}_{3}{ }^{-}$の分析試薬nitron ${ }^{86,87)}$ を用いて $\mathrm{NO}_{3}{ }^{-}$と反応 させ, 電子顕微鏡で観察するもので, 可溶性の $\mathrm{NO}_{3}-$ の分析に適用できる.

本来, 乙の方法は Bigg 等が開発し88), Bigg's technique と呼ばれ，後に Ayersが改良したものであ り ${ }^{89)}$ ， Mamane 等の方法はさらにそれを改良したに すぎないが, $\mathrm{NO}_{3}{ }^{-}$を $\mathrm{NO}_{2}{ }^{-}, \mathrm{SO}_{4}{ }^{2-}, \mathrm{C} \ell^{-}, \mathrm{I}^{-}$, $\mathrm{CO}_{3}{ }^{2-}$ と区別することができる. 反応点の大きさはもと の粒子の大きさ, nitron フィルムの厚さ, 反応が起て る時の RHに支配されるが，後者の 2 つのパラメーター を固定させた時, 反応点之粒子の粒径は相関関係を有 するため，反応点/粒径の比を算出することができ，乙 の比を利用して試料中の $\mathrm{NO}_{3}-$ 粒子の粒径を知ること ができる．また，ての方法では， $\mathrm{NaNO}_{3}$ と $\mathrm{NH}_{4} \mathrm{NO}_{3}$ を 区別することができ，清浄空気に対して数分，污染大 気に対しては数秒の捕集時間でことたりる.

彼等は乙の方法で発電所周辺, 都市地域, 後背地等 の大気中の粒子を測定し, $\mathrm{NO}_{3}{ }^{-}$は $1 \mu \mathrm{m}$ 以上の粒径 に多いととを示している。 また発電所周辺では, $\mathrm{NO}_{3}{ }^{-}$ は少なく，0.2〜1.0 $\mu \mathrm{m}$ には検出されず， $1 \sim 3 \mu \mathrm{m} て ゙$ あ極めて少ないてと, 後背地 (Ceder 山) では0.2〜

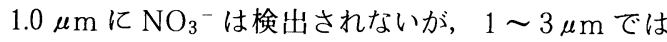
$\mathrm{NO}_{3}$-が19\%を占めること，石油精製所周辺では，1〜 $3 \mu \mathrm{m}$ で $\mathrm{NH}_{4} \mathrm{NO}_{3}$ が $8 \%, \mathrm{NaNO}_{3}$ が $30 \%$ を占めるて とおよび都市部（Boulder）では, 細かい領域に $\mathrm{NO}_{3}{ }^{-}$ は検出されないが，大きい粒子中では $\mathrm{NO}_{3}-$ が $40 \%$ を 占めること等を報告している.

\section{6 人為的な一次粒子としての $\mathrm{NO}_{3}$ - 排出}

人為的活動による粒子状 $\mathrm{NO}_{3}-$ の大気中への直接的 な排出は移動発生源においても固定発生源においても 考えられる. 移動発生源に扔いては，特に触媒車によ る排出が懸念されていた。触媒コンバーターは排気中 の $\mathrm{CO}$ や $\mathrm{HC}$ 濃度を低減させるし， $\mathrm{NO}_{2}$ をより毒性の 少ない物質に変える点で利点があるが, 一方で $\mathrm{SO}_{4}{ }^{2-}$, $\mathrm{NO}_{3}$ 一を生成する可能性が指摘されてきた．乙れに基 ゔき,Appel 等は米国に扔いて触媒車を導入する前 (1974 年夏) に, 自動車に由来する $\mathrm{SO}_{4}{ }^{2-}$ および $\mathrm{NO}_{3}{ }^{-}$ が存在するから゙うかを調べたが90), 両者ともその存 在が否定された。

Dzubay 等は1976 年 10 月, Los Angeles の高速道 路で車から排出される $\mathrm{SO}_{4}{ }^{2-}, \mathrm{NO}_{3}{ }^{-}$等測定した ${ }^{91)}$. これらの燃焼生成物は主に細かい粒子中に存在すると 
考えられるため， $0 \sim 2.4 \mu \mathrm{m} と 2.4 \sim 20 \mu \mathrm{m}$ の二段に分 級して捕集したが，バックグランドの值より高い值は 見いだされなかった。

また，我々が交通量の多い道路端で捕集した粒子状 物質中の $\mathrm{NO}_{3}$-濃度は $5 \mu \mathrm{g} / \mathrm{m}^{3}$ 以下がほとんどで, 他 の地域よりとりわけ高い值は見いだされなかった ${ }^{66,921}$.

一方, 固定発生源からも高濃度の $\mathrm{NO}_{3}{ }^{-}$加排出され ているという報告がない931。

Parungo 等は Los Angeles 南部の石油精製地帯の 近くで，前述の Nitron 反応 一電子顕微鏡を利用し, 分級した粒子中の $\mathrm{NO}_{3}$-を分析した結果, 排出直後の 煙条 (Plume) 中では $\mathrm{NO}_{3}{ }^{-}$は極めて少ないが，風下 方向に行くにしたがって，そのなか含まれる $\mathrm{NO}_{3}{ }^{-}$ の割合が多くなることより，粒子状 $\mathrm{NO}_{3}-$ の二次的生 成を推定している ${ }^{94)}$.

\section{7 粒子状 $\mathrm{NO}_{3}$-の自然的発生とバックグランド浱度}

自然的発生による粒子状 $\mathrm{NO}_{3}$ - は主に大気起源と土 壤起源に分けられる. 他に火山ガスの凝縮水等も考え られている. 大気起源の $\mathrm{NO}_{3}-$ について, Hoeringは 雨水中のその起源を熱力学的同位体効果を計算するて とによって探っている ${ }^{95)}$ 。それによると ${ }^{14} \mathrm{NH}_{3} \rightarrow{ }^{14} \mathrm{~N}$ $\mathrm{O}_{3}{ }^{-},{ }^{15} \mathrm{NH}_{3} \rightarrow{ }^{15} \mathrm{NO}_{3}{ }^{-}$に抢りる同位体効果は, $1.004_{3}$

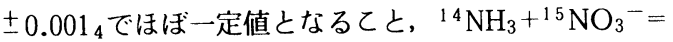
${ }^{15} \mathrm{NH}_{3}+{ }^{14} \mathrm{NO}_{3}$-の平衝は重い同位体の方がより酸化 体になりやすいという原則に反するてと， ${ }^{14} \mathrm{~N}_{2}+2$

${ }^{15} \mathrm{NO}={ }^{15} \mathrm{~N}_{2}+2{ }^{14} \mathrm{NO}$ ついては，大気中窒素の ${ }^{15} \mathrm{~N} /$ ${ }^{14} \mathrm{~N}$ がほぼ一定であるのに対し,雨水中の $\mathrm{NO}_{3}$-のそれ は一定しない等の理由から， $\mathrm{NO}_{3}{ }^{-}$は $\mathrm{NH}_{3}$ より生成さ れるとしている. Moore 屯その後同様の研究を行なっ ている ${ }^{96)}$.

Blanco 等は Texas の El Paso 周辺で六段のステー ジを持つアンダーセン・インパクターを用いて捕集し た粒子を $\mathrm{KBr}$ とともに小さい錠剤状に成型し，ビーム コンデンサーを用いIRで $\mathrm{NO}_{3}$-を測定し, $\mathrm{KNO}_{3}$ と $\mathrm{NaNO}_{3}$ を大気中から検出している43)。乙のなかには 土壌からのまいあがりによるものが多く含まれている あのと考えられる.

Reiter 等は中央ヨーロッパ（ドイッ，GFR南部）の 山間部で1971 年 11 月〜1973 年 12 月に粒子を捕集し, 202の試料の平均值として, $\mathrm{NO}_{3}$ については0.924 $\mu \mathrm{g} / \mathrm{m}^{3}$ の值 $\left(\mathrm{SO}_{4}{ }^{2-}: 3.147 \mu \mathrm{g} / \mathrm{m}^{3}, \mathrm{NH}_{4}{ }^{+}: 1.295 \mu \mathrm{g} / \mathrm{m}^{3}\right)$ を 示している ${ }^{97)}$.

Robinson 等の見つもりによると, 地球全体で 1 年 間に $462 \times 10^{6}$ トンの $\mathrm{NO}_{3}{ }^{-}$が生成され，そのうち降雨 により $366 \times 10^{6}$ トンが，降塵により $96 \times 10^{6}$ トンが除去 されるとしている98)

\section{8 気体状 $\mathrm{HNO}_{3}$ の大気中での挙動}

主にろ紙法により，世界各地で測定された $\mathrm{HNO}_{3}$ 濃 度の一例を表12亿示す。

Okita 等は粒子状 $\mathrm{NO}_{3}{ }^{-}$- と $\mathrm{HNO}_{3}$ を分別定量した結

表12 世界各地で測定された気体状 $\mathrm{HNO}_{3}$ 濃度の一例

\begin{tabular}{|c|c|c|c|c|c|c|c|c|c|}
\hline \multicolumn{3}{|c|}{$\mathrm{NO}_{3}$ 一濃度 $\left(\mu \mathrm{g} / \mathrm{m}^{3}\right)$} & \multirow{2}{*}{$\mathrm{n}$} & \multirow{2}{*}{ 測 定 場 所 } & \multirow{2}{*}{ 測定期間 } & \multirow{2}{*}{$\begin{array}{l}\text { 時間 } \\
(\mathrm{h})\end{array}$} & \multirow{2}{*}{ 捕 集 法 等 } & \multirow{2}{*}{ 備 考 } & \multirow{2}{*}{ 文 献 } \\
\hline 平 均 & 最 高 & 最 低 & & & & & & & \\
\hline$(27.2)$ & (55.3) & $(16.6)$ & 54 & Riverside (CA) & $77.7 \sim 10$ & 5 分 & FT-IR & 高濃度時 & 30 \\
\hline 2.3 & 3.9 & 0.7 & 9 & Pittsburg (CA) & 79.2 & 8 & $\mathrm{NaC} \ell$ 含浸万紙 & & 24 \\
\hline 2.5 & 4.0 & 0.8 & 8 & & & & ナイロンろ紙 & & 24 \\
\hline 4.69 & 16.0 & 1.21 & 13 & Upton (NY) & $78.6 \sim 7$ & $2 \sim 18$ & $\mathrm{NaC} \ell$ 含浸ろ紙 & & 23 \\
\hline (8.3) & (28) & & & West Covina (CA) & 73.8 & 10分 & クーロメトリー & & 15 \\
\hline 0.39 & 1.5 & 0.05 & 10 & 筑波山 & 75.10 & (2) & ) & & 4 \\
\hline (7.5) & $(23.0)$ & $(0.9)$ & 30 & 東京 & $75.7 \sim 8$ & 7 & $\mathrm{NaC} \ell$ 含浸乃紙 & & 4 \\
\hline (1.1) & $(2.5)$ & $(0.04)$ & 24 & 東京 & 76.1 & & & 日平均 & 4 \\
\hline & (28) & (3) & & Los Angeles & 74.夏 & 1 & & & 21 \\
\hline & (22) & (3) & & St. Louis & & & \}ナイロンろ紙 & & 21 \\
\hline & (8) & $(0)$ & & Dayton & & & & & 21 \\
\hline & (38) & & & 英, Harwell & & & & & (99) \\
\hline & $(3.2)$ & $(0.1)$ & & Gothenburg & $77.8 \sim 11$ & 24 & $\mathrm{NaC} \ell$ 含浸ろ紙 & & 99 \\
\hline & (9.5) & $(0.2)$ & & Rörvik & & & & & 99 \\
\hline
\end{tabular}

濃度のうち,（）内は図等より読みとったり，換算した值. 
果 ${ }^{4)}$, 東京で夏期に平均值で $2 \mathrm{ppb}$ 近い濃度で $\mathrm{HNO}_{3}$ を検出している．また $\mathrm{HNO}_{3}$ はオキシダントと良い相 関関係にあるが，粒子状 $\mathrm{NO}_{3}$ 一はオキシダントとその ような関係がないことを示した．また粒子状 $\mathrm{NO}_{3}$-濃 度は季節変化が少ないのに対し, $\mathrm{HNO}_{3}$ は夏期のほう が冬期よりも数倍高い濃度を示すと報告している。さ らに後背地（筑波山）においては夏期に $\mathrm{HNO}_{3}$ のほう が $\mathrm{NO}_{2}$ より高い濃度を示すととを報告している. 図-7 に彼等によって測定された $\mathrm{NO}_{2}$ 濃度と $\mathrm{HNO}_{3}$ 濃度との 関係を示す.

一方, Miller と Spicer はクーロメトリーで $\mathrm{HNO}_{3}$ を 測定した結果, $\mathrm{O}_{3}$ と $\mathrm{HNO}_{3}$ との間に良い相関関係が あるととを示している ${ }^{15)}$ (図-8)。さらに Spicer が測 定したLos Angeles 等での $\mathrm{HNO}_{3}$ の経時変化を図-9 に示す ${ }^{21)}$. Los Angeles では $\mathrm{HNO}_{3}$ は $\mathrm{O}_{3}, \mathrm{PAN}$ と

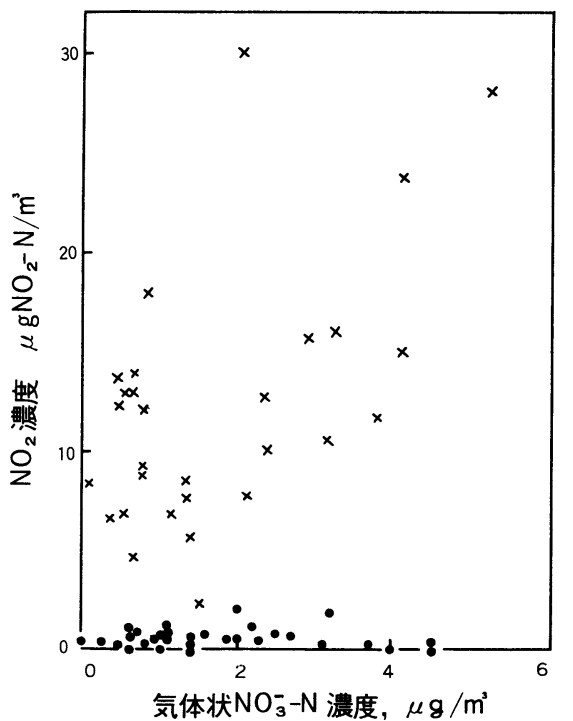

x：東京・国立公衆衛生院（1975年 7 月 25 日～ 8 月 30 日）

・: 筑波山（1975年6月25日〜 7 月 3 日）

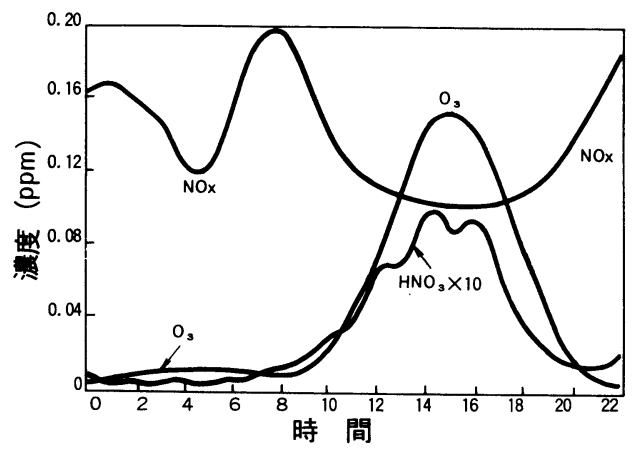

図-8 West Covina (California) における $\mathrm{HNO}_{3}$ 濃 度の経時変化*) の一例15) 1973 年 8 月

*)経時変化: 化学的には適正な表現ではないが, diurnal vari ation に相当する污染物質濃度の時間変動を示す用語として本 報では使用した。
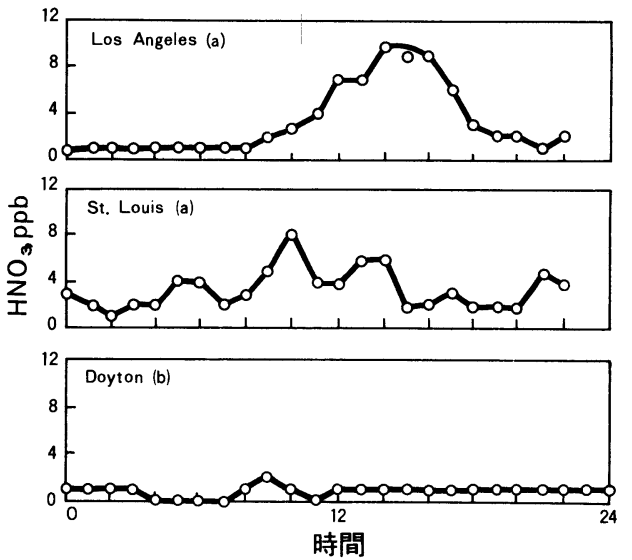

1974 年夏 a) 5 週間の平均値, b) 4 週間の平均値

図-9 都市部における $\mathrm{HNO}_{3}$ の経時変化 211

図-7 $\mathrm{NO}_{2}$ 濃度と気体状 $\mathrm{NO}_{3}{ }^{-}$濃度との関係 ${ }^{4)}$
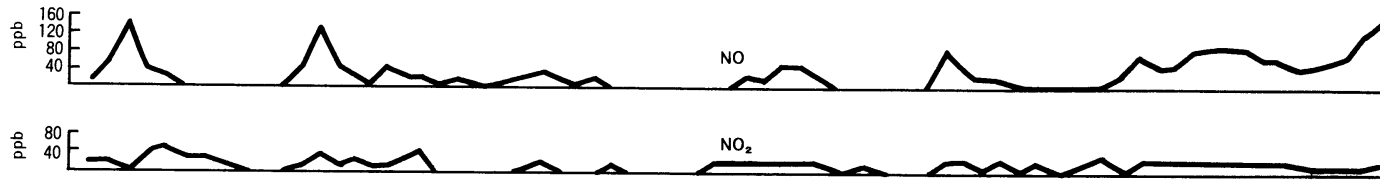

$\mathrm{NO}_{2}$

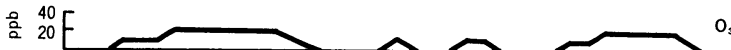

$\stackrel{2}{2} 1$

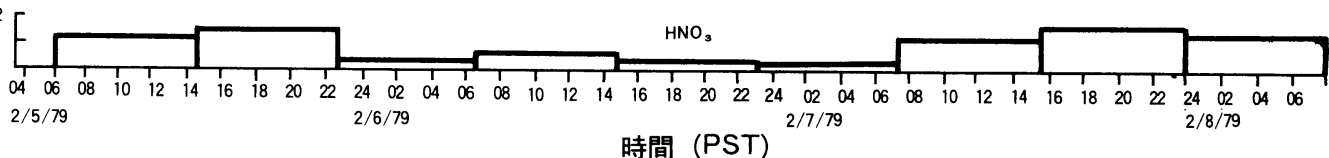

図-10 Pittsburg (California) における $\mathrm{NO}, \mathrm{NO}_{2} \quad \mathrm{HNO}_{3}$ および $\mathrm{O}_{3}$ の経時変化 24) 
表13 石英織維万紙と $\mathrm{NaC} \ell$ 含浸万紙を用いて捕集 された大気中の粒子状 $\mathrm{NO}_{3}-$ と気体状 $\mathrm{HNO}_{3}$ 濃度の 比較 ${ }^{231}$

\begin{tabular}{|c|c|c|}
\hline \multicolumn{2}{|c|}{$\mathrm{NO}_{3}$ 一濃度 $\left(\mu \mathrm{g} / \mathrm{m}^{3}\right)$} & \multirow[t]{2}{*}{$\frac{\text { 気体状 } \mathrm{NO}_{3}{ }^{-}}{\text {全 } \mathrm{NO}_{3}^{-}}$} \\
\hline 粒子状 & 気体状 & \\
\hline 1.16 & 1.21 & 0.51 \\
\hline 0.28 & 1.62 & 0.85 \\
\hline 0.82 & 1.74 & 0.68 \\
\hline 2.27 & 3.27 & 0.59 \\
\hline 0.55 & 5.07 & 0.90 \\
\hline 2.24 & 5.94 & 0.73 \\
\hline 3.94 & 1.99 & 0.34 \\
\hline 0.55 & 4.25 & 0.89 \\
\hline 0.66 & 7.69 & 0.92 \\
\hline 1.30 & 5.76 & 0.83 \\
\hline 0.88 & 3.89 & 0.82 \\
\hline 2.63 & 2.48 & 0.49 \\
\hline 3.59 & 16.0 & 0.82 \\
\hline
\end{tabular}

Upton（New York）で1978年 6 月〜 7 月に測定
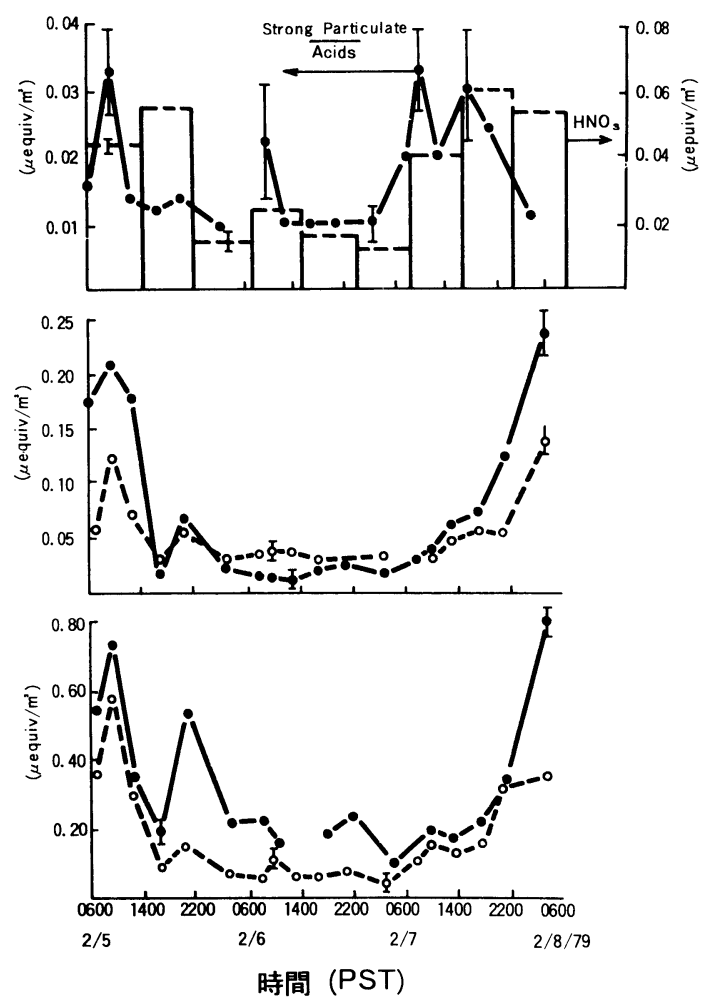

図-11 Pittsburg (California) における $\mathrm{HNO}_{3}$, $\mathrm{NH}_{3}$ およびェアロゾル成分の経時変化 ${ }^{24)}$
表14 気体状 $\mathrm{HNO}_{3} /$ 粒子状 $\mathrm{NO}_{3}$-濃度比の一例

\begin{tabular}{|c|c|c|c|l|c|}
\hline \multicolumn{3}{|c|}{$\mathrm{HNO}_{3} /$ 粒子状 $\mathrm{NO}_{3}{ }^{-}$} & \multirow{2}{*}{$\mathrm{n}$} & \multirow{2}{*}{ 測 定 場 所 } & 文献 \\
\cline { 1 - 3 } 平 均 & 最 高 & 最 低 & & & \\
\hline 4.34 & 11.65 & 0.51 & 13 & Upton & 23 \\
0.84 & 4.00 & 0.19 & 9 & Pittsburg & 24 \\
$0.70>$ & 2.52 & $0.20>$ & 11 & Riverside & 30 \\
0.30 & 1.00 & 0.04 & 10 & 筑波|l & 4 \\
$(0.42)$ & $(0.89)$ & $(0.01)$ & 24 & 東京 (76.1) & 4 \\
$(1.91)$ & 3.50 & 1.00 & 5 & Rörvik & 99 \\
$(0.72)$ & 1.75 & 0.32 & 5 & Göthenburg & 99 \\
\hline
\end{tabular}

\section{表中の記載条件は表 $9 ， 12$ 亿闹じ}
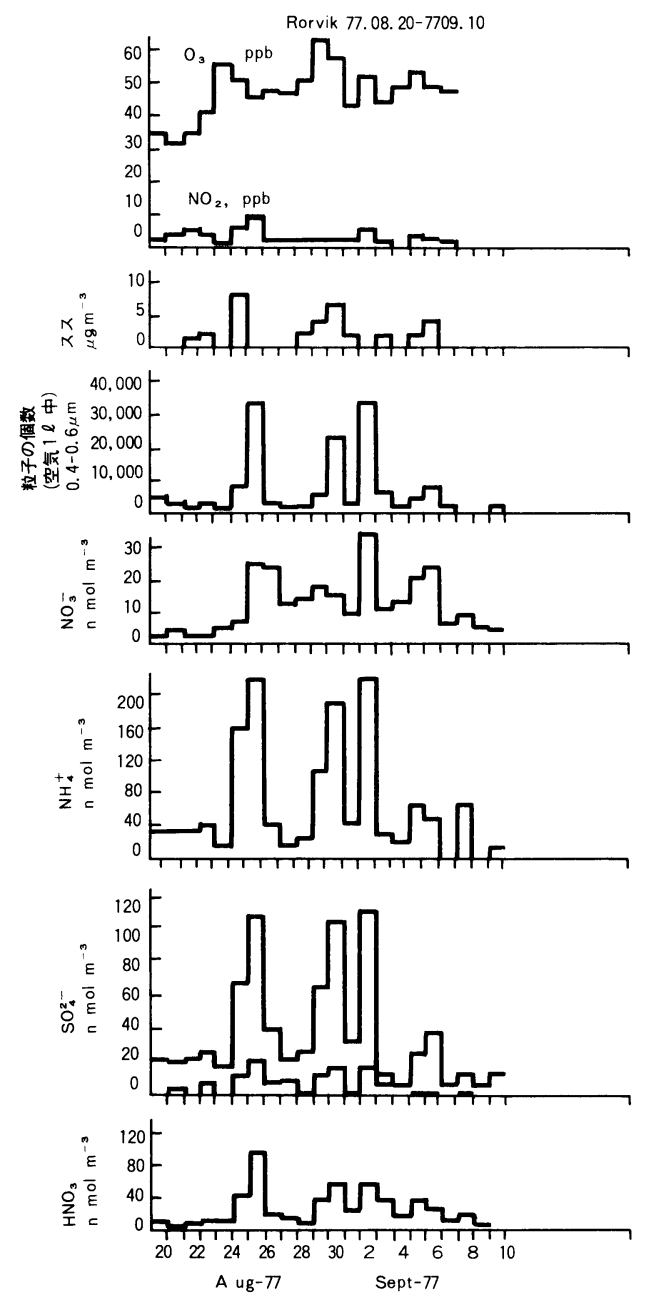

図-12Rorvik (スエーデン) における $\mathrm{HNO}_{3}$ と他の 污染物質濃度の経時変化 ${ }^{991}$

（1977年 8 月20日～9月10日） 
同様の挙動を示し, 夜〜朝にかけて低く, 昼間に高く なり, 午後 2 時頃にピークを示す. その後PAN は比 較的ゆっくり濃度が下がるが, $\mathrm{HNO}_{3}$ は急激に濃度が 下がる. Spicer は, それは粒子状 $\mathrm{NO}_{3}{ }^{-}$生成に関係 していると推定している. また PAN $/ \mathrm{HNO}_{3}$ 比は Los Angeles で $1 \sim 3$, 特にスモッグの強い日の午後には 1 ～20值を示すとしている.

Appel 等も $\mathrm{HNO}_{3}$ を測定したが24), 彼等はSpicer のようには, $\mathrm{HNO}_{3}$ と $\mathrm{O}_{3}$ 間の相関関係が認められな かったとしている（図-10）。しかしながら，Appel 等 の測定時期は冬期で, $\mathrm{HNO}_{3}$ と $\mathrm{O}_{3}$ はともに濃度が低 いということに基づいているのかもしれない．彼等は さらに, $\mathrm{HNO}_{3}$ はエアロゾル中の $\mathrm{H}^{+}$とだけ良い相関 関係があったと報告している（図-11）. $\mathrm{HNO}_{3} /$ 粒子状 $\mathrm{NO}_{3}$ 一比は 0.19〜4.000範囲で変動するが, 図-11 か ら見れば， $\mathrm{HNO}_{3}$ と粒子状 $\mathrm{NO}_{3}$ 一はまったく相関関係 がないというより，気象的因子の影響を受けるととも に，時間的ズレがあるようにも見える。

Forrest 等は13の試料に拈いて $\mathrm{HNO}_{3} /$ 粒子状 $\mathrm{NO}_{3}{ }^{-}$ 比は0.51〜11.65の間で変動し, 平均4.34 と極めて高い 值を報告している（表13） ${ }^{23)}$ 。乙の值の時間的変化 はわからないが，あまり規則性はなさそうである。

GrennfeltはスエーデンのGothenburg周辺で $\mathrm{HNO}_{3}$ を測定したが, 都市部より後背地でのほうが高い濃度 を示すと報告している ${ }^{99)}$. それに対し, 粒子状 $\mathrm{NO}_{3}-$ は都市部のほうが高い值である。また $\mathrm{HNO}_{3}$ は粒子の 個数濃度, $\mathrm{NH}_{4}+, \mathrm{SO}_{4}{ }^{2-}, \mathrm{H}^{+}$と同様の挙動を示す のに対し，粒子状 $\mathrm{NO}_{3}$-とはあまり良い相関関係がな かった（図-12）。基本的には，海を渡ってくるイギ リス等からの “屯らい公害”を考えているようである が，上記の現象を $\mathrm{HNO}_{3}$ が large alkaline particles に吸着されることで説明できると報告している。

な技，表14に測定值から算出された $\mathrm{HNO}_{3} /$ 粒子状 $\mathrm{NO}_{3}$-比の一例を示す.

このように見てくると, $\mathrm{HNO}_{3}$ は夏期のほうが冬期 より濃度が高く，それは $\mathrm{O}_{3}$ との間で相関関係が良い 乙と, また $\mathrm{HNO}_{3} /$ 粒子状 $\mathrm{NO}_{3}$-比は予想されるより 高く, $\mathrm{HNO}_{3}$ と粒子状 $\mathrm{NO}_{3}$ - との相関関係が良くない こと等が多くの研究者によって示されているようであ り, $\mathrm{HNO}_{3}$ の生成機構と $\mathrm{HNO}_{3} \rightarrow$ 粒子状 $\mathrm{NO}_{3}-$ の変 換を考える際，極めて重要な野外調査の結果と思わ れる。

また, Brosset ${ }^{1001}$ や大喜多101) は雨水中の $\mathrm{NO}_{3}-$ および雨水の酸性化に対する $\mathrm{HNO}_{3}$ の役割の大きい乙
とを示唆しているが，我々が神戸で雨水中の $\mathrm{NO}_{3}$ - と $\mathrm{NO}_{2}$ 一の挙動を調べた結果からも102), また後背地の 雨水中の $\mathrm{NO}_{3}{ }^{-}$濃度加ら屯103), 大気中の $\mathrm{HNO}_{3}$ の 存在が推定された。

\section{引用文献}

$52 ）$ 昭和 45 年度 53 年度, 国設大気污染測定網（N A S N ) 測定結果, 環境庁 $(1972 \sim 1980)$.

53）野々村豊子他, 大気污染研究 10，629（1975）。

54）平野耕一郎他, 京誌, 10,576 (1975).

55）鈴木正雄他, 同誌, 11，329（1976）.

56）木藤嘉正他, 同誌, 11，146（1976）.

57）小林禧樹他, 同誌, 11, 125（1976）.

58）石田哲夫他, 同誌, 11，101（1976).

59）野々村豊子他, 同誌, 11, 46（1976）.

60）池沢 正他, 第18回大気污染研究全国協議会大会講演要 旨集, p 116 (1977).

61）小山太八郎他, 第19回大気污染学会講演要旨集, p 186 (1978).

62）小林禧樹他, 同誌, p 182 (1978).

63）池沢 正他, 第20回大気励染学会講演要旨集, p 176 (1979).

64）谷本高敏他, 同誌, p 444 (1979).

65）村野健太郎他, 同誌, p 440 (1979).

66）玉置元則, 平木隆年。梅田弘志, 兵庫県公害研究所研究 報告, 10，19（1978）。

67) J. S. Sandberg, D. A. Levaggi, R . E . DeMandel, W. Siu, J. Air Poll. Control Assoc., 26, 559 (1976).

68) G. M. Hidy et al ., ibid. , 25, 1106 (1075).

69) K. C. Heidorn, ibid., 28, 803 (1978).

70) J. L. Moyers, L. E. Ranweiler, S. B. Hopf, N. E. Korte, Enziron. Sci. Technol., 11, 789 (1977).

71) R. Dams, J. Billiet, C. Block, M. Demuynck, M. Janssens, Atmos. Environ.. 9, 1099 (1975).

72) M. Demuynck, K. A. Rahn, M. Janssens, R. Dams, ibid . , 10, 21 (1976).

73) B. R . Appel, E. L. Kothny, E. M. Hoffer, G. M. Hidy, J. J. Wesolowski, Environ. Sci. Technol., 12, 418 (1978).

74) D. R . Cronn, R. J. Charlson, R. L. Knights, A. L, Crittender, B. R. Appel, Atmos. Environ., 11, 929 (1977).

75）寺部本次, 産業公害, 12,968（1976）.

76) R. E. Lee, R. K. Patterson, Atmos. Environ., 3 , 249 (1969).

77) D. A. Lundgren, J. Air Poll. Contol Assoc., 20, 603 (1970).

78) R. J. Gordon, R. J. Bryan, Environ. Sci. Technol., 7, 645 (1973).

79) P. T. Cunningham, ibid., 8, 131 (1974).

80) R. E. Lee, Jr., S. Goranson, ibid., 10, 1022 (1976).

81) S. Kadowaki, Atomos. Environ., 10, 39 (1976).

82) S. Kadowaki, ibid., 11, 671 (1977).

83) A. H. Moskowit z, E P A Report, $600 / 3-77-053,1977$.

84) M. V. Walker, C. J. Weschler, Environ. Sci Technol., 14, 594 (1980).

85) Y. Mamane, R. F. Pueschel, Atmos. Enriron., 14, 629 
(1980).

86) J. Ueno, I, Sano, Bull Chem. Soc Japan, 44, 637 (1971).

87) A. Tateda, H. Murakami, ibid., 47, 2885 (1974).

88) E. K. Bigg, A. Ono, J. A. Williams, Atmos. Enziron., 8, 1 (1974).

89) G. P. Ayers, ibid., 12, 1227 (1978).

90) B. R. Appel et al. , Prepr. Pap. Am. Chem. Soc. Nat l. Meet.

Div. Environ. Chem. 16, 37 (1976).

91) T. G. Dzubay, R. K. Stevens, L. W. Richards, Atmos. Environ., 13, 653 (1979).

92）鳥橋義和, 玉置元則, 吉岡昌徳, 辻本三郎丸, 沖典男, 平木隆年, 高田亘啓, 兵庫県公害研究所研究報告, 8, 1 (1976).

93) W. M. Henry, K, T. Knapp, Enziron. Sci. Téchnol., 14, 450 (1980).

94) F. P. Parungo, R. F. Pueschel, D. L. Wellman, Atmos Enitiron., 14, 509 (1980).
95) T. Hoering, Geochimca et Cosmochimica Acta., 12,97 (1957).

96) H. Moore, Atmos. Enviren., 11, 1239 (1977).

97) R. Reiter et al. , ibid., 10, 841 (1976).

98) E - Robinson, R. C. Robbins, J. Air Poll. Control Assoc.,

20, 303 (1970).

99) P. Grennfelt, Atmoso. Environ., 14, 311 (1980).

$100)$ C. Brosset, "Atmospheric Formation, Dispersion and De-position of Acid Substances, "Presented at the Spring Meeting of the Swedish Association for Water Hygiene, Gothenburg, 9 10 May, 1978.

101）大喜多敏一, 公害と対策, 13，732 (1977).

102）玉䈯元則，平木隆年，日化，1980，1169.

103）玉置元則，平木隆年，環境技術，9.865（1980）

創刊誌紹介

NEW JOURNAL

\section{環境アセスメントレビュー（季刊）}

Environmental Impact Assessment Review (Quarterly) (ISSN 0195-9255)

自然を保護しようとする連動と,開発を進めようと する動きは，常に相皮する二面性をもっている。この 二面性を融和させ, 調和点を求めるための有力な手法 が, 環境影響事前評価, 略して環境アセスメントであ る。この環境アセスメントは，その重要性がますます 高まっている。

このような世界的な情勢を反映して，去る 3 月に， 標記の尃門誌「環境アセスメントレビュー (Environ mental Impact Assessment Review) 」が創刊された。 従来は，M I T (マサチュセッツ工科大学) から,ロッ クフェラ一財団の援助により，独自に不定期の研究報 告として出され，関係者の間では，注目されていた。 このたび，Plenvm社から，本格的季刊誌として公刊さ れることになった。編集委員長には，M I T 都市計画 部主任教授のL.E. Sussk 博士があたり, 常任編集者 を同じくM I T 建築設計研究室のR.R. Packard教授
が扎当している。体裁は，B 5 をやや小型にした大き さで，創刊男（3月号）は100ページである。内容は, コメント (Comment), 埨説 (Viewpoint), 解説 (Fea ture Articles), 分野別論文 (Departments), 国際展 望(International Perspectives), ネットワーク(Net works)から構成されている。卷韻の「編集方針」にお いて，新しい分析技術，测定手法を公表するとともに， とくに理論と実際とのギャップを埋めることに重点を 置きたいと述べられている。当面，アセスメントの問 題として，银期間にわたる影響評価，自然環境におよ ぼす二次影響，社会的影響評価に対する技術的ジレン マ等のさし迫った問題解決に役立っことが期待される。 環境アセスメント関係の技術者にはもちろんのこと， その他, 行政関係者, 環境衛生, 環境工学, 地域開発, 建設工学, 自然保護など, 幅広い分野の人達に役立つ 専門誌といえよう. 年間購読料は79ドル。 